\title{
Social class and the emergent organised sporting habits of primary-aged children
}

\author{
Sharon Wheeler \\ Edge Hill University, UK \\ Ken Green \\ University of Chester, UK and Inland Norway University of Applied Sciences, Norway \\ $\&$ \\ Miranda Thurston \\ Inland Norway University of Applied Sciences, Norway
}




\begin{abstract}
This paper reports on the patterns of participation in organised sports of youngsters coming towards the end of primary school, with a view to identifying emergent sporting habits in relation to social class gradients. The data for the study were generated via 90 semi-structured interviews with parents and children from 62 families. The data revealed differences in organised activity participation (both at and beyond school) between an 'under-class' and combined middle-class groups of children, as well as within-class gradients among the middle-class sub-groups. There were, for example, substantial differences between the underclass group and the combined middle-class group in terms of both the average number of bouts of organised sport participation and the repertoire or variety of sports engaged with. In effect, the mid- and upper-middle-class children were already sporting and cultural omnivores by the final years of primary schooling. We conclude that while the primary school organised sporting 'offer' may be neither a sufficient nor even a necessary contribution to the emerging sporting habits of mid- and upper-middle-class children, for under-class children it is likely to be necessary even though it may still prove, in the longer run, insufficient.
\end{abstract}

\title{
Keywords
}

Children, primary school, organised sports, habits, class 


\section{Introduction}

Until relatively recently, the promotion of sport participation has focused on the life-stage of youth - as the crucial period for the formation of enduring attachments to sport $^{1}-$ rather than childhood and, therefore, secondary rather than primary schools (see de Knop and de Martelaer, 2001; Engström, 2008; Flintoff and Scraton, 2001; Jakobsson, Lundvall, Redelius, and Engström, 2012); Pot, Verbeek, van der Zwan, and van Hilvoorde, 2016). Jakobsson et al. (2012), for example, explored the 'cultural conditions' of youth for later life sports participation, concluding that those young Swedes who remained involved in sport clubs during their teens tended to possess sporting dispositions as well as sporting and cultural assets (or capital). In a similar vein, Engström's (2008) four-decade longitudinal study examined how a complex of individual, social and environmental factors in youth influenced adherence to sport and physical activity in later life, including the ways in which differences in sporting experiences and cultural capital acquired were reflected in exercise habits in middle-age. In tune with the findings of Roberts and Brodie (1992), among others (see, for example, Haycock and Smith, 2012), Engström (2008) identified what he referred to as "sporting breadth" (and Roberts and Brodie, 1992, termed "wide sporting repertoires") as significantly related to later exercise habits, more so than either sports club membership or time spent engaged in activities during youth. Thus, in one way or another, Engström (2008), Jakobsson et al. (2012), and Roberts and Brodie (1992) have all pointed to the significance of sporting 'breadth' (Engström, 2008) or 'repertoires' (Roberts and Brodie, 1992) for the kinds of sporting capital and habits/habitus that appear to predispose youngsters towards lifelong participation, as well as how these tend to be class-related if not class determined. The attention now being paid to primary-aged children is an expression of the growing belief that the aforementioned sporting habits emerge and show signs of becoming established much

\footnotetext{
${ }^{1}$ Sport is defined broadly to include not only institutionalised, competitive, and physically vigorous activities but so-called lifestyle sports and physical recreation more generally (Green, 2010).
} 
earlier in life than the life-stage of youth (see Birchwood, Roberts and Pollock, 2008; Haycock and Smith, 2012; Wheeler, 2014).

As far back as 1997, Evans, Davies and Penney observed how a wealth of research supported the claim that not only curricular physical education (PE) but also extra-curricular provision in the primary sector was a "critical site of influence" for children's thoughts and practices in relation to physical activity and sport (Evans et al., 1997, p.39). More than a decade on, Dismore and Bailey (2010) noted how the transition from primary to secondary school remained a significant event in children's attitudes towards and behaviours in PE. Latterly, Walters, Payne, Schluter and Thomson (2015, p.241) have referred to "[T]he childhood years ... as a crucial time when ongoing participation in physical activity can be nurtured and maintained". Against this backdrop, this paper reports on the patterns of participation in organised sports of children, from varying social class locations, coming towards the end of primary school, with a view to identifying emergent sporting habits and the related repertoires that may sustain longer-term sporting involvement (Birchwood et al., 2008). The paper draws on data from a wider study (Wheeler, 2013) of class-specific patterns of parenting in relation to inequalities in children's education and leisure.

\section{Classes and class fractions}

Two main social class groupings emerged from the over-arching study: a group tentatively described as an 'under-class' element of the working-class (on the basis of income, employment situation and prospects) and a middle-class (see Table 1). The broad middleclass grouping could be usefully divided into three fractions (based primarily on income and attendant lifestyles) - lower-middle-class, mid-middle-class, and upper-middle-class. Until the 1980s it was conventional to treat the various lower class fractions as part of "a unitary 
working class within which there were different layers" (Roberts, 2015, p.141). Since then, however, "it has become increasingly commonplace to recognize the existence of a so-called 'precariat' - a precarious group amidst the proletariat - including those not working but who want to work, part-time employees who want longer hours, and the working poor" (p.141; emphasis in the original). This precariat - or 'squashed bottom' as Roberts (2015) calls it no longer appear part of a traditional working-class consisting of trained and skilled workers "who occupy the much better paid, more secure jobs" (Roberts, 2015, p.141). Thus, for many sociologists, increasing proportions of the working-classes are living in economically deprived and residentially segregated, as well as socially isolated communities (Cole, Batty, and Green, 2011), which have become, to all intents and purposes, separated from the rest of society (Dorling, 2011). In this study, therefore, the under-class group has been labelled thus - rather than, for example, the more conventional lower-working-class epithet, or even precariat - on the basis that, in this study at least, the under-class families shared many of the characteristics that disadvantage children in an increasingly marketised education system (see Evans, 2007; Gillies, 2005; Reay, 2006) and who come to form what amounts to an underclass - an excluded section of the larger working-class. Most of the relevant families in the present study survived on benefits, resided in distinct localities, and experienced multiple forms of deprivation. It is debatable whether such families have - as a result of high levels of unemployment and 'cuts' in the state welfare system - come to form an under-class or whether they remain simply fractions of a disorganised and disjointed working-class (Roberts, 2001). In our view, however, the group labelled under-class in this study did not fit traditional working-class criteria. Nor did it seem appropriate to distinguish them as 'rough' or 'struggling to cope' working-class fractions as some have done (see Vincent and Ball, 2007). They did, however, display many and, in some cases, all of the features of an underclass - in so far as, occupying the very lowest position in a hierarchy of class, they were in 
effect distinguished by their 'exclusion', marginalized even from mainstream working-class families - and are, therefore, referred to as such. By the same token, the study revealed the kind of fragmented middle-class identified by Savage et al. (2013) among others. The importance of drawing attention to intra-class diversity within the middle-class has been widely recognised in the sociology literature (see Irwin, 2009).

\section{INSERT TABLE 1 SOMEWHERE HERE}

\section{Methods}

The data for the study were generated via 90 semi-structured interviews with parents and children (40 boys and 23 girls) from 62 families, together with a Family Information Questionnaire (FIQ) - completed and returned prior to the commencement of the interviews. Ethical approval for the study was gained from the relevant University Research Ethics Committee. Mothers, fathers and children were all required to give their informed consent prior to participation in interviews. In keeping with good practice relating to the involvement of youngsters below the age of 16 years in research, the children's consent was actively sought alongside that of their formal guardians (Aldersen and Morrow, 2011; Morrow and Richards, 1996). Their inclusion was dependent on the youngsters' assent, independent of their parents.

The families in the study were recruited through 12 primary schools (11 state and one independent) located within a three-mile radius of a small city in the north-west of England. The schools were selected on the basis of several characteristics, namely the number of pupils eligible for free school meals; the number of pupils with special educational needs; Key Stage 2 examination results; Ofsted/ISI (Office for Standards in Education/Independent Schools 
Inspectorate) report information; and the Indices of Multiple Deprivation for the school catchment areas. A table detailing these characteristics was compiled for all of the schools within the pre-determined radius of the city centre in question. The schools likely to yield families with particular socio-economic characteristics were then contacted. Twelve schools distributed information packs to Year 5 and 6 pupils (nine to 11 years old) to be taken home to their parents. The information packs contained an outline of the project along with the FIQ. Where feasible, both parents and the Year 5 (ages 9-10) or 6 (ages 10-11) 'target' child were interviewed. There were several instances where only the mother was interviewed as the father and/or child were not available or willing to be interviewed, something not uncommon in research involving families (see Vincent and Ball, 2007). The parental interviews were between one and three hours duration while the children's interviews lasted approximately 15 minutes. The data on children's weekly participation in 'activities' were derived from the following question (and related follow-up questions) asked of the parents and corroborated, where necessary, by the children: 'Can you tell me about any organised activities, clubs, or groups that your child is involved in both inside and outside of school?' ('What activities do they do?' 'Where do they do them?' 'Who do they do them with?'). An 'activities checklist' was used to record activities in a standardised way on each day of the week. The interviews also included questions on the parents' involvement (if any) in their child's activities/clubs/groups; their aspirations for their child; and their perspectives on parenting.

\section{Findings}

In what follows we will pick out the main features of the under- and various middle-class fractions' children's participation in school-based extra-curricular and beyond school leisuretime organised sports at the time of their interview. Though the focus in this paper is on sports, the other organised cultural and educational activities of the children are provided by 
way of drawing a fuller picture of the children's emerging cultural and educational as well as sporting capital. Table 2 provides an overview of the data to be discussed, while Tables 3 to 6 provide more detailed information regarding patterns of participation. As indicated at the foot of each table, an asterisk (*) next to the activity indicates that the activity was school-based: that is to say, provided at and by schools and delivered primarily by teachers but also (and, increasingly, it appears) by so-called 'adults other than teachers' (AOTTs) - including sport coaches.

Before proceeding further we need to insert a caveat regarding our use of descriptive statistics in the form of percentages and proportions. In short, we provide descriptive statistics in order to simply describe what is going on in our data; that is, simple summaries about the percentages and proportions of our samples who, for example, engaged in organised sport. We are not suggesting that these statistics are in any way inferential. In other words, we are not trying to reach conclusions that can be generalised, in a statistical sense, beyond our samples to the organised sports participation of children at large, in similar social class fractions or schools. Because the sample was not representative we cannot talk in terms of statistical significance. We have not, therefore, sought to establish, let alone indicate, whether the differences found between the class fractions and schools might have happened by chance. Rather, we have proceeded in the inductive tradition by examining the descriptive statistics to reveal latent patterns (Glaser, 2003), using these as the basis for theorizing. In this regard we aim to provide a number of plausible theoretical generalizations regarding the emergent sporting habits of youngsters rather than statistical inferences.

\section{INSERT TABLE 2 SOMEWHERE HERE}


The children's participation in organised sporting activities

The under-class children

The 14 (eight male, six female) under-class children participated in 17 bouts of organised leisure-time activity, of which $12(71 \%)$ were sporting activities and five were cultural activities (such as drama, musical theatre and art) during a typical week at the time of the interviews. Two of the 14 under-class children undertook no leisure activity at all during the week, while over a third (36\%; five of 14 ) did no sport. The number of participatory bouts per child among the under-class group ranged from none to three, with the average being 1.33. With the exception of one child (who took part in three activities during the 'typical' week) none of the remainder undertook more than two bouts of sporting activity during the week.

\section{INSERT TABLE 3 SOMEWHERE HERE}

Six different sport activities were featured in the 12 bouts of participation among the underclass children: four (33\%) of football, three of street dance, two of basketball, one swimming, one dance and one tag rugby. In the case of two boys and one girl, football was the only sport they undertook. The only other game played was basketball, undertaken by one boy in leisure-time beyond school. In short, not only was there relatively little involvement in leisure-time organised sport among children in this group, there was relatively little variety in the types of organised activities in which they participated. Thus, a feature of the under-class children's profiles was their restricted sporting repertoires: of the 14 youngsters in this group, none took part in the three or more activities that Roberts and Brodie (1992), among others (see Birchwood et al., 2008; Haycock and Smith, 2012; Smith, 2006), have identified as a potentially crucial threshold for generating the kinds of sporting habits and predispositions 
(what Bourdieu, 1977, 1984, and Elias, 2001, termed 'habitus') likely to sustain enduring participation in sport. The average number of organised sports each child engaged in during the week was less than one (0.9).

Overall, 58\% (seven) of the instances of participation among this group were school-based; that is, they were provided at and by schools and delivered by either teachers or AOTTs. Three of the four instances of football among these children were school-based. Unsurprisingly, being school-based, the majority of the bouts of participation took place during the week rather than at weekends. Only one child had an organised sports activity at the weekend.

Unlike the three middle-class sub-groups, the organised sport participation of the under-class children was not embedded in a relatively broad range of other cultural activities. Only three of the 14 children (21\%) took part in cultural activities: one bout each of either art club, church group and musical theatre and two bouts of drama.

While there were degrees of overlap, much of the descriptive data for organised sports participation among the under-class group of children - total bouts of sports participation, the average number of bouts per child, the number of different activities undertaken, the venues, use of the weekend and so forth - stood in marked contrast to the three middle-class subgroups and the mid-middle-class and upper-middle-class in particular.

\section{The lower-middle-class children}

The 11 (eight male, three female) lower-middle-class children in the study engaged in a total of 48 bouts of organised leisure activity during the 'typical' week, of which $69 \%$ (33) were 
organised sporting activities and 15 were cultural activities. All 11 youngsters participated in sport at least once during the week, with a maximum of seven bouts (sometimes involving several bouts and activities on the same day - typically one activity immediately after school and another later on the same evening) and an average of three per child; that is to say, more than three times the average for children from the under-class group. More than half of the 33 sports participatory bouts (18) involved football. The pre-eminence of football $(55 \%$ of organised sport activity in a typical week) was even more striking among the lower-middleclass children than it was among the under-class group - where one-third (four of 12) of the bouts of participation involved football. Only three of the 11 lower-middle-class youngsters (two boys, one girl) did not play football at least once.

It was also apparent that while the variety of activities undertaken by the lower-middle-class group were more extensive than those of the under-class group, the difference was small: overall children in the former participated in eight different sports compared with six in the latter. In addition to the under-class group's portfolio of football (in which two of the three girls in the lower-middle-class group were engaged), dance, basketball, tag rugby and swimming, the only activity that more than one of the lower-middle-class children engaged in was running. Not only were the organised sports portfolios of the lower-middle-class group of children quite similar to that of the under-class group, the lower-middle-class portfolios appeared restricted when compared with the other middle-class sub-groups - by comparison with whom the lower-middle-class children did proportionately fewer bouts of participation in organised sport and far fewer types of organised activities.

\section{INSERT TABLE 4 SOMEWHERE HERE}


An average of 1.7 different sports per child meant that the lower-middle-class group fell substantially below the threshold of three different sports characteristic of the aforementioned wide sporting repertoires. In part, this picture is a function of the smaller numbers in the under-class (14) and lower-middle-class (11) groupings when compared with the mid-middleclass (21) and upper-middle-class (17) groups. Nonetheless, at the level of the individual children in each group, participatory patterns were relatively consistent; that is to say, reasonably typical participation patterns emerged within each group distinguishing them from the other groups. We return to this point in the summary of the findings.

Just over one-third (12 of 33; 36\%) of the organised sporting bouts of the lower-middle-class children were school-based - compared with $58 \%$ for the under-class youngsters - and half of these (six of 12) were football. Almost one-third (10 of 33) of participatory bouts occurred during the weekend. This compares with a relative dearth of organised sports participation on the weekend among children from the under-class group: one solitary activity of basketball in a typical week. While the sporting portfolios of the lower-middle-class children were relatively similar to those of the children in the under-class group, their patterns of involvement in organised sport - in terms of participation beyond the school gates and at the weekends - bore stronger resemblance to the other middle-class sub-groups than the underclass group. Similarly, sports participation among the lower-middle-class children tended to be embedded in a wider range of leisure activities, including Cubs and Scouts, Guides ${ }^{2}$, music, art, drama and church group.

\footnotetext{
2 The Scout and Girl Guides organisations are century-old movements that ostensibly aim to support young people in their physical, mental and spiritual development. They purport to develop character and service, particularly through outdoor activities. Cub scouts are junior scouts.
} 


\section{The mid-middle-class children}

The 21 (12 male, nine female) mid-middle-class children participated in 120 bouts of leisuretime activity, of which 75 (63\%) were sporting activities and 45 were cultural activities. All 21 children did some leisure activity during the week, and almost all (20 of 21) did some form of organised sport on at least several occasions. The number of sports participatory bouts per child ranged from one to 10 among this sub-group, with the average being approximately 3.6. This was more than three times that of the average for the under-class children and, although only slightly higher than the lower-middle-class group, the greater variety of sports undertaken by the mid-middle-class youngsters was noteworthy.

\section{INSERT TABLE 5 SOMEWHERE HERE}

The 75 bouts of sporting activity undertaken by this group were made up of a wide variety (26) of organised sports or activities, ranging from football - a staple for boys from all social groups - and other activities that were also common among the under- and lower-middleclass groups (for example, running and swimming and, albeit to a lesser extent, dance), through a wider range of games (such as cricket, hockey and netball) provided by schools, to more esoteric activities - both at school (fencing, for instance) and beyond (such as horseriding, kayaking, ice-skating, trampolining, ju-jitsu and triathlon). Thus, a feature of the midmiddle-class children's participation was the wider sporting repertoires of the group as a whole, and a good number of individuals in particular. The average number of different sports per child engaged in by the mid-middle-class group was 2.9. Indeed, of the 21 children in the mid-middle-class group, two-thirds (14) took part in the threshold of three or more activities identified earlier as desirable for generating the kinds of sporting habits and habitus likely to sustain ongoing, even lifelong, participation in sport. It was this group - with wider 
sporting repertoires - who were most likely to take part in particular sports (for example, football, athletics and dance) on several occasions during the week.

Just under one-third $(31 \% ; 23$ of 75$)$ of the bouts of sports participation among the midmiddle-class group were school-based. In marked contrast to the under-class group - where little participation took place beyond school and very little at the weekend - 29\% (22 out of 75 sessions of organised sport) of sports participation among the mid-middle-class children took place at the weekend and on Saturday in particular.

As with the other middle-class sub-groups, the mid-middle-class children's sports participation tended to be embedded in a range of leisure activities, including music, Cubs and Scouts, Guides, music, art, drama and church group.

\section{The upper-middle-class children}

The 17 (12 male, five female) upper-middle-class children in the study participated in 98 weekly bouts of leisure-time activity, of which $62(63 \%)$ were sporting activities and 36 were cultural leisure activities. All 17 children participated in organised leisure activities during the week and all did some form of organised sport. The number of participatory bouts per child ranged from one to five among the upper-middle-class group, with the average being approximately 3.6.

\section{INSERT TABLE 6 SOMEWHERE HERE}

As with the mid-middle-class children, in particular, the 62 bouts of organised sport undertaken by the upper-middle-class group were made up of a wide variety of activities (24 
different organised sports), ranging from football through activities common among the lower-middle-class and under-class groups (football especially) as well as the mid-middleclass group (running and swimming, for instance) and a wider range of games (such as hockey, rugby and netball) provided at school, to more esoteric activities, both school-based (for example, fencing) and beyond (karate, golf, horse-riding, water-skiing and triathlon). There were, however, some subtle differences between the mid-middle-class and uppermiddle-class sub-groups, in that the upper-middle-class children tended to have engaged more in cultural and educational activities (such as flute lessons, chess club, orchestra, and newspaper club) while the mid-middle-class children did more outdoor activities. It was also noticeable that dance was less commonplace among the mid- and upper-middle-class girls.

As with the mid-middle-class youngsters, the breadth of the sporting repertoires of the uppermiddle-class group as a whole was noteworthy. The average number of different sports per child engaged in by the upper-middle-class group was three. As was the case with the midmiddle-class group, just over two-thirds (11) of the 17 youngsters in the upper-middle-class group took part in the threshold of three or more organised sport activities during the week and, once again, the upper-middle-class children were most likely to take part in particular sports (for example, football and swimming) on several occasions during the week.

In terms of location, just under one-third (20 of $62 ; 32 \%)$ of the upper-middle-class bouts of organised sports participation were school-based, compared with two-thirds $(42 ; 68 \%)$ beyond school. Here again - and in marked contrast to the under-class group, where little participation took place beyond school and very little at the weekend - approximately onethird $(21$ of $62 ; 34 \%)$ of sports participatory bouts among the upper-middle-class children took place at the weekend, and on Saturdays in particular. 
In line with the other middle-class groupings, though even more so, the upper-middle-class children's sports participation was embedded in a wide range of leisure activities, including music, Cubs and Scouts, Guides, music, art, drama and church group.

Another noteworthy finding involved the relative prominence in children's leisure-sport profiles of school provision vis-à-vis voluntary and commercial provision (see Table 7). It was evident that the lower down the social class gradient children and their families were, the greater their tendency to rely on school provision for organised sporting opportunities, both relatively and sometimes absolutely. While the activities that the under-class children undertook were almost entirely school-based, those of the middle-classes as a whole - and the mid- and upper-middle-classes in particular - were generally a mixture of school-based and voluntary club or commercial provision. School provision appeared most significant, therefore, for the under-class children. That said, it was noticeable that schools provided at least a seed for, if not necessarily a kernel of, some of the organised sporting activities undertaken by children in all groups. In the case of the upper-middle-class children, the range of sporting activities is likely to reflect the fact that independent schools are especially able to provide a wide range of specialist sports facilities and coaching and, therefore, relatively esoteric after-school clubs. There are also likely to be sporting opportunities associated with some of the cultural activities these youngsters engage with, such as Cubs, Scouts and Guides.

INSERT TABLE 7 SOMEWHERE HERE

\section{Summary}


This exploratory analysis has revealed class-related variations in primary school children's participation in organised sporting and cultural activities. Those under-class children who engaged with organised sports took part in a relatively narrow (i.e. one or two) range of different activities on a couple of separate occasions during the week. Their activities tended to be gender stereotypical (football for the boys and dance for the girls), almost exclusively located at and provided by their primary schools and were pretty much the only leisure activities they took part in. By contrast, all of the lower-middle-class children engaged with organised sports, taking part on several occasions during the week in several different - but usually conventional - organised sports. Some were provided by their primary schools, although many were not. Once again, participation tended to be gender stereotypical. The lower-middle-class sports were part of a wider - but not much wider - leisure portfolio than the under-class youngsters. However, like the under-class group, many of the lower-middleclass children fell somewhat short of the threshold of three different activities, in the course of the week, believed to constitute a wide sporting repertoire (Roberts and Brodie, 1992). Allin-all, there was little variety in the types of organised activities that the under-class children participated in and the lower-middle-class children did fewer types of organised activities compared to the mid- and upper-middle-class children.

The mid-middle-class children engaged extensively with organised sports, taking part on most days during the week in a broad repertoire of different sports - around the threshold of three - including conventional as well as less conventional activities. Some were provided by their primary schools but many were not. The mid-middle-class group were more likely than the under- and lower-middle-class group to take part on Saturdays. While participation remained relatively gender stereotypical, there were noticeable examples of gendered sporting boundaries being crossed. Almost everything about the mid-middle-class group was 
replicated in the upper-middle-class group, only more so. The latter were, however, more likely to surpass the threshold of three different organised sporting activities during the week.

All-in-all, the higher their social class grouping the more likely youngsters were to take part in a greater number, wider variety and differing types or categories of organised sports (and, for that matter, leisure activities more generally) on a more regular basis. These activities ranged from traditional games (including rounders, netball, rugby, cricket and, most notably football), newer ball games (for example, basketball), racket games (such as badminton), (modern) dance of various kinds, athletic activities (running, cycling, gymnastics) and outdoor and adventurous activities (and water sports, such as canoeing, in particular). The higher middle-class groupings - the mid- and upper-middle-class children - were also more likely to engage in more exclusive sports (such as diving, horse-riding, fencing, and rowing) as well as a wide range of less exclusive but seemingly less popular conventional sports (including badminton, gymnastics, ice-skating, trampolining and tennis).

In the next section, we will reflect upon the key findings from the study before concluding with the implications for policy towards primary school PE.

\section{Discussion}

As indicated above, it is important to be circumspect and cautious about the findings from this exploratory analysis of an unrepresentative sample. The patterns in children's organised sports participation revealed in this paper may nevertheless be illuminative, helping to refine tentative hypotheses regarding the ways in which class (and gender) and school provision might shape early and emerging participatory habits. Thus, the findings should be viewed as a starting point for future research rather than as definitive - raising a number of questions 
related to differences, not to say, inequalities in children's early sporting experiences, particularly in and beyond the primary school.

The first point of note from this study is the significance of class (and, more specifically, class gradients) for participation. The patterns of participation in organised sporting activities tended to vary according to social class as well as a within-class gradient in the case of the middle-class sub-groups of children. The data revealed variation in organised activity participation between the under-class and combined middle-class groups alongside some subtle differences among the latter - especially between the lower-middle-class children and the other two middle-class sub-groups. There were large differences between the under-class grouping and the combined middle-class group in terms of both the average number of bouts of organised sports participation and the repertoire or variety of sports engaged with: the middle-class children, as a whole, participated more in a wider variety of organised sports, more often. In effect, the mid- and upper-middle-class children were already sporting and cultural omnivores (Peterson and Kern, 1996) by the final years of primary schooling: they participated in a wide range of different types of activities (some quite commonplace, others more esoteric) within and beyond sport. All-in-all, there were class differences in the volume of sports participation, the type of sports participated in and the attendant sporting portfolios, and the distribution of bouts of participation across the week as well as the venues used. The impact of class was multi-faceted. With this observation in mind, the tendency for uppermiddle-class children to be engaged in more educational activities while the mid-middle-class children undertook more outdoor activities might plausibly be taken to indicate that the former are required (by their parents) to forego a degree of sporting involvement in pursuit of wider cultural and educational capital. 
Several activities were relatively classless but one especially so. Among all groups, the single activity provided by schools which featured prominently (in the leisure sport repertoires of boys) was football. Football dominated the sporting profile of the boys from all groups but the under- and lower-middle-class boys in particular. If there was one activity which appeared, however, to epitomise class-related variation it was swimming. Only one of the under-class children received formal swimming lessons, though several of the under-class parents noted that their children had been taught to swim informally by themselves in the past. The rest of the under-class children had not been taught how to swim, either formally or informally. By contrast, all bar one of the middle-class children had undertaken formal swimming lessons from a young age. Some were still doing lessons at the time of the interviews while others had moved on to swimming clubs or other water-based activities. While most had finished formal swimming lessons, in many cases those had been replaced by another organised sporting activity.

Children from all social class groupings took part in activities that their schools provided. Indeed, this provision broadened the sporting portfolios of very many of the youngsters even some of those in the mid- and upper-middle-class groups. For the under-class children this was inevitable given the pre-eminence of school provision in their sporting portfolios. For the lower-middle-class children, for example, their schools provided dodgeball, running club and orienteering alongside the staples of football, netball and dance. It was among the mid- and upper-middle-class children, nevertheless, where the impact of school provision on sporting repertoires was most apparent. As well as the staple activities, the schools of the upper-middle-class children, for instance, provided an extended range of conventional sports (such as cricket, football, netball, hockey and rugby) but were also more likely to offer a swimming club and some minority sports, such as fencing and cross-country. That said, 
judged by participation, the combined sporting provision of the mid-middle-class schools covered a slightly wider range of organised sporting opportunities than all the other schools, including the independent ('public') school. What needs to be borne in mind here is the tendency of youngsters from both the mid- and upper-middle-class groups (and the latter, in particular) to make extensive use of voluntary and commercial sporting provision beyond the school gates, in addition to any available school provision. In the case of both mid- and upper-middle-class children, school provision of sporting opportunities may serve to reinforce and extend their already wide sporting repertoires.

Particularly noticeable with regard to the upper-middle-class children (the vast majority of whom attended an independent school) was the range of opportunities their school provided for wider cultural activities, ranging from animation, newspaper and sewing clubs to art and drama and a range of musical clubs (guitar, piano, violin and orchestra, for instance). The mid-middle-class children's schools also provided a variety of very similar, although more restricted, 'cultural' clubs - especially music clubs. The wider leisure contexts of the midand upper-middle-class children suggests that if they are not playing organised sport then that is likely to be because they have other emergent leisure interests. For these children, their schools might be seen as initiating, extending and reinforcing interests and capabilities in a kind of 'virtuous' circle.

The relative significance of weekdays and the weekend was also noteworthy. There were middle- and upper-middle-class children who had an organised sporting activity on every weekday and most days of the week as a whole. Many of the children, including some lowermiddle-class children but none from the under-class group, had days when they did more than one organised activity, typically one after school followed by another later in the evening. 
The activities that they did were generally a mixture of school-based and voluntary clubs as well, on occasion, as commercial provision.

Organised sporting activities could be undertaken on any day of the week, although Fridays and Sundays were generally quieter. Participation tended, nevertheless, to be focused between Monday to Thursday - exclusively so in the case of the under-class children - and Tuesday and Wednesday in particular. It was mid- and upper-middle-class youngsters who made extensive use of the weekend and Saturday especially. It is worth keeping in mind, however, that what the youngsters participated in would have been circumscribed by what their schools offered - especially in the case of the under-class children. Because most of the upper-middle-class children attended an independent school they were likely to have benefitted from a more extensive leisure or extra-curricular 'offer' than those attending schools in the state sector. In relation to the so-called school 'offer', it was unsurprising to find that the under-class children in particular but also the lower-middle-class children generally participated in the relatively less costly activities.

It was also notable that school provision appeared to facilitate some bouts of participation. Among the mid-middle-class group, for example, several children took part in particular activities that occurred in schools on a particular day (e.g. running club on Tuesday and orienteering on Wednesday).

Finally, there was some notable variation in patterns by gender. The boys, and the mid- and upper-middle-class boys especially, were more likely to take part in more sports than the girls. Among the mid-middle-class group, for example, while females were more likely to be towards the lower range of sports participatory bouts (two to five), one-third of the 12 boys 
took part either once or twice. Nonetheless, almost half (four of 9) of the females in the midmiddle-class group had wide sporting repertoires; that is to say, they took part in three or more different sports during the course of the week. Across all class fractions, football was the most popular organised activity among the boys. The only activity that resembled a standout organised activity among the girls was dance, but its popularity bore no comparison with football among the boys. Dance was one activity where boys were more likely to cross gender boundaries while football performed the same function for girls. Our findings suggest a good deal of continuity in relation to gender with Shropshire and Carroll's (1998, p.156) two-decade old study of final year primary school children's choices: that is to say, the boys remained "more likely to participate in the team sports traditionally taught in PE whilst the girls spent more of their time engaged in sports not usually included in the curriculum."

\section{Conclusion}

While extra-curricular sporting provision tended to be widespread in the primary schools of the mid- and upper-middle-class youngsters in this study, this may be of little consequence if, as appears increasingly apparent, the leisure-sport habits of many middle-class (especially mid- and upper-middle-class) youngsters are more likely to be established from an early age within middle-class family cultures: the sporting repertoires most likely to lead to lifelong participation have been built during childhood in sports-active families (Roberts, 2016). Extra-curricular sporting provision for these groups may merely be the 'icing on the cake' and neither necessary nor sufficient in terms of impacting upon their long-term adherence to sport. That function is likely to have been usurped by parents and family, beyond school.

By contrast, extra-curricular school provision could have profound significance for underclass children, in particular, as well as those of the working classes as a whole and even the 
lower-middle-classes. This is because it is these groups who are largely or almost entirely reliant upon school provision of sporting opportunities (and a range of activities in particular) for their sport participation. Thus, if "[c]hildhood, not youth, is probably the really critical life stage for laying secure foundations for long-term careers in sport" (Roberts, 2016, p.23), then primary school provision may be crucial for under-class children. It is our contention, therefore, that while many middle-class youngsters are likely to have their sporting repertoires developed by their families (see Quarmby, 2016; Wheeler, 2014), very many working-class and under-class youngsters in particular are not. Here it may be possible for primary schools to make a difference. At the very least, it seems clear that, by default (and often of necessity), under-class parents rely upon what the school has to offer.

The findings from the study suggest, therefore, that the greatest need is to be found in schools in under-class catchment areas (and probably, by extension, schools in working-class areas as a whole) as well as those in lower-middle-class catchment areas, albeit to a lesser extent. In such schools, availability and cost are especially important factors in participation. In relation to gender differences, there is a normative, deeply-entrenched expectation of boys that they will play sport and football, in particular. This norm is not established among girls of primary age. Our findings suggest, therefore, that policy discussion needs to be couched not so much in terms of what is wrong with girls but, rather, what is wrong with primary sports provision; in other words, how can it be tailored more specifically to girls' nascent and emerging interests, such as they are.

In terms of the timing of extra-curricular PE provision in primary schools, if uptake can be taken as a guide to provision then it seems that activities need to be made available in the early to middle portion of the week, at the very least. Tuesdays and Wednesdays were the 
most popular days across all groups whereas Fridays and Sundays appeared, in many cases, sacrosanct. It is also important to keep in mind potential clashes with children's other commitments. In the case of the under- and lower-middle-class groups in our study, these tended primarily to be the arts (school-based) and Cubs/Scouts and Girl Guides (out of school).

With the policy implications of our findings in mind, we need to insert a note of caution. The activities listed here should not be seen as anything approaching a definitive list that either hold special appeal to youngsters of this age (although some, of course, do - football being the prime example). Nor, for that matter, should they be seen as forming the basis of an ideal type extra-curricular (or even curricular) PE - far from it - for three reasons. First, they represent a mix of what: (i) some of the children's parents have encouraged and constrained their children to undertake; (ii) teachers and schools provide; and, (iii) the children themselves choose to do. As Roberts (2016, p.19) observes: "Children play at times, with friends, in places and at activities that are chosen and supervised by adults - parents, teachers and others to whom the care of dependents is entrusted". Second, it is inevitable that, as well as reflecting the influence of parents and the facilitation of teachers and schools, coaches and clubs, participation will also reflect degrees of ability and talent on the part of the youngsters. Third, with a focus on organised sports, this study does not include the wide range of socalled 'lifestyle' or 'informal' sports or activities which - as well as being, by definition, more $a d$ hoc - are evidently increasingly popular among children and young people. These include informal versions of conventional sports (such as football and basketball), as well as the various forms of boarding, blading and cycling well-established in the free-time of many youngsters, away from school. In this regard, it is necessary to remember that while it is unlikely that these informal activities would have pushed the under-class children over and 
above the threshold of three different activities on a regular (in this case, weekly) basis, they may well have done so for the lower-middle-class group. Nor are we suggesting that the absence of wide-scale extra-curricular sporting provision is the sole let alone main explanatory factor in the relatively impoverished sporting repertoires of under-class children. Rather, by implication, this is likely to be explainable in terms of cultural as well as material constraints; in other words, not merely the economic conditions of the under-class families but also an absence of the norms for concerted cultivation of sporting capital far more common among mid- and upper-middle-class families.

This was a study of children in the final two years of primary schooling shortly to move into secondary schooling, where sports participation traditionally peaks during the early years. Thus, the repertoires these children possess at the time of transition may well be crucial. Roberts (2016, p.20) reminds us that "Childhood is the life stage when there is mass recruitment into sport" with the consequence that "the vast majority of young people enter the post-child life stage with foundations in sport already laid." However, "these foundations are not all equally strong" (Roberts, 2016, p.20). This is apparent in the leisure-time involvement in organised sporting activities of the under-class children in this study but also, albeit to a lesser extent, the lower-middle-class children. While the primary school 'offer' may be neither a sufficient nor even a necessary contribution to the emerging sporting habits and habitus of mid- and upper-middle-class children, for under-class children it is likely to be necessary even though it may still prove, in the longer run, to be insufficient. Although it is far from self-evident that processes such as primary PE can be a "substitute for the power of family socialisation which operates daily throughout childhood" (Roberts, 2016, p.23), there are grounds for thinking that with one group at least there is nothing to be lost and everything to be gained. 


\section{References}

Aldersen, P and Morrow, V (2011) The Ethics of Research with Children and Young People. A Practical Handbook. London: Sage.

Birchwood D, Roberts K and Pollock G (2008) Explaining differences in sport participation rates among young adults: Evidence from the South Caucasus. European Physical Education Review 14(3): 283-300.

Bourdieu P (1977) Outline of a Theory of Practice. Cambridge, Cambridge University Press.

Bourdieu P (1984) Distinction: A Social Critique of the Judgment of Taste (Translated by R. Nice). Harvard: Harvard University Press.

Bowles R and O'Sullivan M (2012) Rhetoric and reality: the role of the teacher in shaping a school sport programme. Physical Education and Sport Pedagogy 17(3): 303-316.

Charmaz K (2006) Constructing Grounded Theory: A Practical Guide through Qualitative. London, Sage.

Cole I, Batty E and Green S (2011) Low-income Neighbourhoods in Britain: The Gap Between Policy Ideas and Residents' Realities. York: The Joseph Rowntree Foundation.

de Knop P and de Martelaer K (2001) Quantitative and qualitative evaluation of youth sport in Flanders and the Netherlands: A case study. Sport, Education and Society 6(1): 35-51. 
Department for Education (DFE) (2014) PE and Sport Premium: An Investigation into Primary Schools. Research brief, September 2014. London: DfE. Downloaded Thursday $2^{\text {nd }}$ October, 2014, 11:20AM.

Dismore H and Bailey R (2010) 'It's been a bit of a rocky start': attitudes toward physical education following transition. Physical Education and Sport Pedagogy 15(2): 175-191

Dorling D (2011) Injustice. Why Social Inequality Persists. Bristol, The Policy Press.

Elias N (2001) The Society of Individuals. London: Basil Blackwell.

Engström, L-M (2008) Who is physically active? Cultural capital and sports participation from adolescence to middle age - A 38-year follow-up study. Physical Education and Sport Pedagogy 13(4): 319-343.

Evans G (2007). Educational Failure and Working Class White Children in Britain. London: Palgrave MacMillan.

Evans J, Rich E, Allwood R and Davies B (2007) Being "able" in a performative culture: Physical education's contribution to a healthy interest in sport? In: Wellard I (ed) Rethinking Gender and Youth Sport. London: Routledge, pp.51-67. 
Evans J, Davies B and Penney D (1997) Making progress? Sport policy, women and innovation in physical education. European Journal of Physical Education 2(1): 39-50.

Flintoff A and Scraton S (2001) Stepping into active leisure? Young women's perceptions of active lifestyles and their experiences of school physical education. Sport, Education and Society 6(1): 5-21.

Gillies V (2005) Raising the 'meritocracy': Parenting and the individualization of social class. Sociology 39(5): 835-853.

Glaser B (2003) The Grounded Theory Perspective II: Description's Remodelling of Grounded Theory Methodology. Mill Valley, CA: Sociology Press.

Green K (2010) Key Themes in Youth Sport. London: Routledge.

Haycock D and Smith A (2012) A family affair? Exploring the influence of childhood sport socialisation on young adults' leisure-sport careers in north-west England. Leisure Studies 33(3): 285-304.

Irwin S (2009) Locating where there action is: Quantitative and qualitative lenses on families, schooling and structures of social inequality. Sociology 43(6): 1123-1140.

Jakobsson, B T, Lundvall, S, Redelius, K, and Engström, L-M (2012) Almost all start but who continue? A longitudinal study of youth participation in Swedish club sports. European Physical Education Review 18(1): 3-18. 
Macdonald D., Rodger S, Ziviani J, Jenkins D, Batch J and Jones J (2004) Physical activity as a dimension of family life for lower primary school children, Sport, Education and Society 9(3): 307-325.

Morrow, V and Richards, M (1996) The ethics of research with children: an overview. Children and Society 10(2), 90-105.

O'Brien W, Belton S-J and Issartel J (2015) Fundamental movement skill proficiency amongst adolescent youth. Physical Education and Sport Pedagogy. Downloaded. $10^{\text {th }}$ March 2015, 11:13am. DOI: 10.1080/17408989.2015.1017451

Peterson R and Kern R (1996) Changing highbrow taste: From snob to omnivore. American Sociological Review 61: 900-907.

Pot N, Verbeek J, van der Zwan J and van Hilvoorde I (2016) Socialisation into organised sports of young adolescents with a lower socio-economic status, Sport, Education and Society, 21(3): $319-338$.

Quarmby T (2016) Parenting and youth sport. In: Green K and Smith A (eds) The Routledge Handbook of Youth Sport. Oxford: Routledge, pp.219-217.

Quick S, Simon A and Thornton A (2010) PE and Sport Survey. London: TNSBMRB/Department for Education. Research Report DFE-RR032. 
Penney D and Harris J (1997) Extra-curricular physical education: More of the same for the more able. Sport, Education and Society 2(1), 41-54.

Reay D (2006) The zombie stalking English schools: Social class and educational inequality. British Journal of Educational Studies 54(3): 288-307.

Roberts K (2001) Class in Modern Britain. Basingstoke: Palgrave MacMillan.

Roberts K (2016) Youth leisure as the context for youth sport. In: Green K and Smith A (eds) The Routledge Handbook of Youth Sport. Oxford: Routledge, pp.18-25.

Roberts K and Brodie D (1992) Inner-City Sport: Who Plays and What Are the Benefits? Giordano Bruno, Culemborg.

Savage M, Devine F, Cunningham N, Taylor M, Li Y, Hjellbrekke J and Miles A (2013) A new model of social class: Findings from the BBC's Great British Class Survey experiment. Sociology 47: 219-250.

Shropshire J and Carroll B (1998) Final year primary school children's PA levels and choices. European Journal of Physical Education 3(2): 156-166.

Skelton C (2000) 'A Passion for Football': Dominant Masculinities and Primary Schooling. Sport, Education and Society 5(1): 5-18. 
Smith A (2006) Young People, Sport and Leisure. A Sociological Study of Contemporary Youth. Unpublished PhD thesis. Chester: University of Chester.

Smith A (2013) Primary school physical education and sports coaches: evidence from a study of School Sport Partnerships in north-west England. Sport, Education and Society. doi:10.1080/13573322.2013.847412

Stuij M (2013) Habitus and social class: a case study on socialisation into sports and exercise. Sport, Education and Society. DOI: 10.1080/13573322.2013.827568. Downloaded 12:28pm, Tuesday $10^{\text {th }}$ March, 2105.

Vierimaa M, Erickson K and Côté J (2016) The elements of talent development in youth sport. In: Green, K and Smith A (eds) The Routledge Handbook of Youth Sport. Oxford: Routledge, pp.464-475.

Vincent, C and Ball S J (2007) 'Making up' the middle-class child: families, activities and class dispositions, Sociology 41(6): $1061-1077$.

Walters S, Payne D, Schluter PJ and Thomson RW (2015) 'It just makes you feel invincible': a Foucauldian analysis of children's experiences of organised team sports. Sport, Education and Society 20(2): 241-257.

Wheeler S (2014) Patterns of Parenting, Class Relations and Inequalities in Education and Leisure. A Grounded Theory. Unpublished PhD thesis. Chester: University of Chester. 
TABLE 1 Class-related characteristics of the families involved in the study

\begin{tabular}{|c|c|c|c|c|c|}
\hline & $\begin{array}{l}\text { Number } \\
\text { of } \\
\text { families }\end{array}$ & $\begin{array}{l}\text { Number } \\
\text { of } \\
\text { parents }\end{array}$ & $\begin{array}{l}\text { Household } \\
\text { income }\end{array}$ & $\begin{array}{l}\text { Parents } \\
\text { with } \\
\text { higher } \\
\text { education } \\
\%(n)\end{array}$ & $\begin{array}{l}\text { Parents in } \\
\text { Standard } \\
\text { Occupational } \\
\text { Groups } 1-3^{3} \\
\%(n)\end{array}$ \\
\hline $\begin{array}{l}\text { Under- } \\
\text { class }\end{array}$ & 14 & 22 & $\begin{array}{l}<£ 10,000- \\
£ 19,999\end{array}$ & 0 & 0 \\
\hline $\begin{array}{l}\text { Lower- } \\
\text { middle- } \\
\text { class }\end{array}$ & 10 & 20 & $\begin{array}{l}£ 20,000- \\
£ 39,999\end{array}$ & $45(9)$ & $35(7)$ \\
\hline $\begin{array}{l}\text { Mid- } \\
\text { middle- } \\
\text { class }\end{array}$ & 22 & 41 & $\begin{array}{l}£ 40,000- \\
£ 89,999\end{array}$ & $71(29)$ & $66(27)$ \\
\hline $\begin{array}{l}\text { Upper- } \\
\text { middle- } \\
\text { class }\end{array}$ & 16 & 32 & $\begin{array}{l}£ 90,000- \\
£ 180,000\end{array}$ & $78(25)$ & $78(25)$ \\
\hline Totals & 62 & 115 & - & 63 & 59 \\
\hline
\end{tabular}

${ }^{3}$ The Standard Occupational Classification (ONS, 2010b) was used to classify parents' occupations on the basis of 9 categories. Group 1 = Managers, directors, and senior officials; Group 2 = Professional occupations; Group $3=$ Associate professional and technical occupations. 
TABLE 2 The children's participation in organised sporting activities during a typical week

\begin{tabular}{|c|c|c|c|c|c|c|c|}
\hline & $\begin{array}{l}\text { Total number of } \\
\text { organised } \\
\text { activities }\end{array}$ & $\begin{array}{l}\text { Percentage }(n) \\
\text { of organised } \\
\text { activities that } \\
\text { were sport }\end{array}$ & $\begin{array}{l}\text { Percentage (n) } \\
\text { of children } \\
\text { participating } \\
\text { in sport } \\
\text { activities }\end{array}$ & $\begin{array}{l}\text { Sport activity } \\
\text { (percentage) with } \\
\text { highest } \\
\text { participation }\end{array}$ & $\begin{array}{l}\text { Mean number of } \\
\text { bouts of organised } \\
\text { sport activity per } \\
\text { child }\end{array}$ & $\begin{array}{l}\text { Percentage }(n) \text { of } \\
\text { sport activities } \\
\text { undertaken at } \\
\text { school }\end{array}$ & $\begin{array}{l}\text { Number of } \\
\text { different } \\
\text { sport } \\
\text { activities }\end{array}$ \\
\hline $\begin{array}{l}\text { Under-class: } 14 \\
\text { children ( } 8 \text { boys; } \\
6 \text { girls) }\end{array}$ & 17 & $71(12)$ & $64(9)$ & Football (33\%) & 0.9 & $58(7)$ & 6 \\
\hline $\begin{array}{l}\text { Lower-middle- } \\
\text { class: } 11 \\
\text { children ( } 8 \text { boys; } \\
3 \text { girls) }\end{array}$ & 48 & $69(33)$ & $100(11)$ & Football $(55 \%)$ & 3.0 & $36(12)$ & 8 \\
\hline $\begin{array}{l}\text { Mid-middle- } \\
\text { class: } 21 \\
\text { children (12 } \\
\text { boys; } 9 \text { girls) }\end{array}$ & 120 & $63(75)$ & $100(21)$ & $\begin{array}{l}\text { Football }(15 \%) \\
\text { Swimming }(15 \%)\end{array}$ & 3.6 & $31(23)$ & 26 \\
\hline $\begin{array}{l}\text { Upper-middle- } \\
\text { class: } 17 \\
\text { children ( } 12 \\
\text { boys; } 5 \text { girls) }\end{array}$ & 98 & $63(62)$ & $100(17)$ & Football (21\%) & 3.6 & $32(20)$ & 24 \\
\hline $\begin{array}{l}\text { Total children: } \\
63 \text { ( } 40 \text { boys; } 23 \\
\text { girls) }\end{array}$ & & & & & & & \\
\hline
\end{tabular}




\begin{tabular}{|c|c|c|c|c|c|c|c|c|}
\hline \multirow{2}{*}{$\begin{array}{l}\text { Family } \\
\text { Number }\end{array}$} & \multirow{2}{*}{$\begin{array}{l}\text { Child's } \\
\text { sex }\end{array}$} & \multicolumn{7}{|c|}{ Day of the Week } \\
\hline & & Monday & Tuesday & Wednesday & Thursday & Friday & Saturday & Sunday \\
\hline 8 & Male & & $\begin{array}{l}\text { Swimming } \\
\text { lesson }\end{array}$ & & Football* & & & \\
\hline 16 & Male & & & & & Art club* & & \\
\hline 18 & Female & & & & & & & \\
\hline 19 & Female & & Church group & & & & & \\
\hline 29 & Male & Basketball & & Street dance* & & & Basketball & \\
\hline 30 & Male & & Tag rugby* & & & & & \\
\hline 37 & Male & & & & Football* & & & \\
\hline 42 & Male & & & & Football* & & & \\
\hline 46 & Male & & Street dance* & & & & & \\
\hline 47 & Female & Drama* & & & Dance & & & \\
\hline 48 & Female & Drama* & Street dance* & & & & & \\
\hline 49 & Male & & & & & & & \\
\hline 53 & Female & & & & & $\begin{array}{l}\text { Musical } \\
\text { theatre }\end{array}$ & & \\
\hline 58 & Female & Football & & & & & & \\
\hline
\end{tabular}

n.b. An asterisk $(*)$ indicates that the activity was school-based. 
TABLE 4 Organised activities of the lower-middle-class children during a typical week at the time of the interviews

\begin{tabular}{|c|c|c|c|c|c|c|c|c|}
\hline \multirow{2}{*}{$\begin{array}{l}\text { Family } \\
\text { Number }\end{array}$} & \multirow{2}{*}{$\begin{array}{l}\text { Child's } \\
\text { sex }\end{array}$} & \multicolumn{7}{|l|}{ Day of the Week } \\
\hline & & Monday & Tuesday & Wednesday & Thursday & Friday & Saturday & Sunday \\
\hline 1 & Female & & Football* & & Dance & & & \\
\hline 17 & Male & Scouts & Running club* & $\begin{array}{l}\text { Dodgeball* } \\
\text { Guitar lesson* }\end{array}$ & Drama* & Junior club & & Hockey \\
\hline 25 & Female & & $\begin{array}{l}\text { Running club* } \\
\text { Guides }\end{array}$ & & Netball* & & & \\
\hline 33 & Male & $\begin{array}{l}\text { Drum lesson* } \\
\text { Art club* }\end{array}$ & Football* & & & & & \\
\hline 39 & Male & Ukulele lesson & Football & & Football* & & Football & Church group \\
\hline 40 & Female & Football & $\begin{array}{l}\text { Swimming } \\
\text { club }\end{array}$ & & Guides & & Football & $\begin{array}{l}\text { Swimming } \\
\text { club }\end{array}$ \\
\hline 45 & Male & & $\begin{array}{l}\text { Football* } \\
\text { Football }\end{array}$ & Church group & & & & Football \\
\hline 51 & Male & $\begin{array}{l}\text { Drama* } \\
\text { Football }\end{array}$ & & $\begin{array}{l}\text { Swimming } \\
\text { club }\end{array}$ & Football* & $\begin{array}{l}\text { Swimming } \\
\text { club }\end{array}$ & $\begin{array}{l}\text { Swimming } \\
\text { club } \\
\text { Football }\end{array}$ & $\begin{array}{l}\text { Swimming } \\
\text { club }\end{array}$ \\
\hline 54 & Male & $\begin{array}{l}\text { Swimming } \\
\text { lesson }\end{array}$ & & Football & Football* & & Football & \\
\hline 55 & Male & & Dance* & Orienteering* & Cubs & & & \\
\hline 56 & Male & $\begin{array}{l}\text { Drama* }^{*} \\
\text { Drum lesson }\end{array}$ & & & & Football & Football & \\
\hline
\end{tabular}

n.b. An asterisk (*) indicates that the activity was school-based. 
TABLE 5 Organised activities of the mid-middle-class children during a typical week at the time of the interviews

\begin{tabular}{|c|c|c|c|c|c|c|c|c|}
\hline \multirow{2}{*}{$\begin{array}{l}\text { Family } \\
\text { Number }\end{array}$} & \multirow{2}{*}{$\begin{array}{l}\text { Child's } \\
\text { Sex }\end{array}$} & \multicolumn{7}{|l|}{ Day of the Week } \\
\hline & & Monday & Tuesday & Wednesday & Thursday & Friday & Saturday & Sunday \\
\hline 2 & Female & & Running club* & Guides & Drama* & Junior club & $\begin{array}{l}\text { Swimming } \\
\text { lesson }\end{array}$ & \\
\hline 4 & Male & Jujitsu & Badminton & $\begin{array}{l}\text { Dodgeball* } \\
\text { Football }\end{array}$ & & Jujitsu & Football & \\
\hline 6 & Female & Violin lesson & Street dance & Netball* & Judo* & & & Hockey \\
\hline 7 & Female & Swim training & $\begin{array}{l}\text { Running club* } \\
\text { Tennis }\end{array}$ & Piano lesson & $\begin{array}{l}\text { Drama* } \\
\text { Stagecoach }\end{array}$ & Junior club & Triathlon club & \\
\hline 9 & Female & Dance & $\begin{array}{l}\text { Running club* } \\
\text { Tennis }\end{array}$ & $\begin{array}{l}\text { Swimming } \\
\text { lesson }\end{array}$ & Art club* & Junior club & Dance & \\
\hline 11 & Male & Basketball & $\begin{array}{l}\text { Football* } \\
\text { Cubs }\end{array}$ & & $\begin{array}{l}\text { Fencing* } \\
\text { Piano lesson* }\end{array}$ & Football & Football & \\
\hline 12 & Male & $\begin{array}{l}\text { Swimming } \\
\text { lesson }\end{array}$ & Guitar lesson* & Cubs & Jujitsu & & & \\
\hline 13 & Male & Cubs & Running club* & $\begin{array}{l}\text { Dodgeball* } \\
\text { Guitar lesson* }\end{array}$ & $\begin{array}{l}\text { Swimming } \\
\text { lesson }\end{array}$ & Junior club & Swim training & \\
\hline 15 & Male & Guitar lesson* & Drum lesson & Cubs & Fencing* & & $\begin{array}{l}\text { Swimming } \\
\text { lesson }\end{array}$ & \\
\hline 23 & Male & Cricket & $\begin{array}{l}\text { Chess club* } \\
\text { Cubs }\end{array}$ & & Football* & & & Hockey \\
\hline 32 & Female & & Badminton & $\begin{array}{l}\text { Glee club* } \\
\text { Brownies }\end{array}$ & Art club* & Junior club & Dance & \\
\hline 35 & Male & $\begin{array}{l}\text { Hockey* } \\
\text { Rugby }\end{array}$ & $\begin{array}{l}\text { Football* } \\
\text { Athletics }\end{array}$ & Tag rugby* & $\begin{array}{l}\text { Judo* } \\
\text { Fencing* }\end{array}$ & & $\begin{array}{l}\text { Athletics } \\
\text { Tennis }\end{array}$ & Rugby \\
\hline 36 & Male & & Running club* & $\begin{array}{l}\text { Dodgeball* } \\
\text { Tennis }\end{array}$ & Art club* & Junior club & & Church group \\
\hline 38 & Female & $\begin{array}{l}\text { Swimming } \\
\text { lesson }\end{array}$ & Horse riding & Glee club* & $\begin{array}{l}\text { Recorder } \\
\text { lesson* }\end{array}$ & & Horse riding & \\
\hline 41 & Male & Art club* & & Cubs & Film club* & & $\begin{array}{l}\text { Kayaking } \\
\text { lesson }\end{array}$ & \\
\hline
\end{tabular}




\begin{tabular}{|c|c|c|c|c|c|c|c|c|}
\hline 43 & Male & Flute lesson* & & $\begin{array}{l}\text { Fencing* } \\
\text { Diving lesson }\end{array}$ & Dodgeball* & & & Swim training \\
\hline 50 & Male & Drama* & Drum lesson* & & & Football & Football & \\
\hline 52 & Female & $\begin{array}{l}\text { Drama* } \\
\text { Gymnastics }\end{array}$ & Piano lesson* & Gymnastics & & Gymnastics & Tennis & \\
\hline 57 & Female & Drama* & Dance* & $\begin{array}{l}\text { Orienteering* } \\
\text { Guides }\end{array}$ & & & $\begin{array}{l}\text { Ice skating } \\
\text { Trampolining }\end{array}$ & \\
\hline 60 & Male & Art club* & Football & $\begin{array}{l}\text { Swimming } \\
\text { lesson }\end{array}$ & & & Tennis & Football \\
\hline 62 & Female & Piano lesson* & Guides & $\begin{array}{l}\text { Swimming } \\
\text { lesson }\end{array}$ & & Theatre train & & \\
\hline
\end{tabular}

n.b. An asterisk (*) indicates that the activity was school-based. 
TABLE 6 Organised activities of the upper-middle-class children during a typical week at the time of the interviews

\begin{tabular}{|c|c|c|c|c|c|c|c|c|}
\hline \multirow{2}{*}{$\begin{array}{l}\text { Family } \\
\text { Number }\end{array}$} & \multirow{2}{*}{$\begin{array}{l}\text { Child's } \\
\text { Sex }\end{array}$} & \multicolumn{7}{|c|}{ Day of the Week } \\
\hline & & Monday & Tuesday & Wednesday & Thursday & Friday & Saturday & Sunday \\
\hline 3 & Male & Guitar lesson* & $\begin{array}{l}\text { Swimming } \\
\text { lesson }\end{array}$ & Football* & Cricket* & & Football & Rugby \\
\hline 5 & Male & Guitar lesson* & Rugby & Football* & & & Rugby & Cricket \\
\hline 10 & Male & Guitar lesson* & & Orchestra* & Cross country* & Church group & $\begin{array}{l}\text { Mountain } \\
\text { biking }\end{array}$ & \\
\hline 14 & Female & $\begin{array}{l}\text { Sewing club* } \\
\text { Piano lesson* }\end{array}$ & $\begin{array}{l}\text { Swimming } \\
\text { club* }\end{array}$ & $\begin{array}{l}\text { Hockey* } \\
\text { Netball* }\end{array}$ & Drama & $\begin{array}{l}\text { Newspaper } \\
\text { club* }\end{array}$ & Dance & \\
\hline 20 & Female & $\begin{array}{l}\text { Orchestra* } \\
\text { Piano lesson* }\end{array}$ & $\begin{array}{l}\text { Violin lesson* } \\
\text { Swimming club }\end{array}$ & $\begin{array}{l}\text { Newspaper } \\
\text { club* }^{*}\end{array}$ & $\begin{array}{l}\text { Animation } \\
\text { club* }\end{array}$ & Chess club & $\begin{array}{l}\text { Swimming club } \\
\text { Chess club }\end{array}$ & Swimming club \\
\hline 21 & Male & & Tennis & & $\begin{array}{l}\text { Cricket* } \\
\text { Football }\end{array}$ & & Football & Golf lesson \\
\hline 22 & Male & $\begin{array}{l}\text { Swimming } \\
\text { lesson }\end{array}$ & Tae Kwondo & & Drum lesson* & & Theatre train & \\
\hline 24 & Male & Piano lesson & $\begin{array}{l}\text { Swimming } \\
\text { club* }\end{array}$ & $\begin{array}{l}\text { IT club* } \\
\text { Badminton* }\end{array}$ & $\begin{array}{l}\text { Basketball* } \\
\text { Drama* }\end{array}$ & & Cycling club & \\
\hline 26 & Female & & $\begin{array}{l}\text { Swimming } \\
\text { club* }\end{array}$ & Netball* & Cross country* & & Tennis & \\
\hline 27 & Male & Basketball* & $\begin{array}{l}\text { Swimming } \\
\text { club* }\end{array}$ & $\begin{array}{l}\text { Football* } \\
\text { Rugby }\end{array}$ & $\begin{array}{l}\text { Keyboard } \\
\text { lesson* } \\
\text { Fencing* }\end{array}$ & Chess club* & & Rugby \\
\hline 28 & Male & & Rowing & Football* & & Drum lesson & Water skiing & \\
\hline 31 & Male & Chess club* & $\begin{array}{l}\text { Violin lesson* } \\
\text { Karate }\end{array}$ & & Karate & Chess club & & Cricket \\
\hline 34 & $\begin{array}{l}\text { Male } \\
\text { (twin) }\end{array}$ & Art club* & & $\begin{array}{l}\text { Cubs } \\
\text { Swimming }\end{array}$ & Karate & Junior club & & \\
\hline
\end{tabular}


34

$\begin{array}{llll} & \begin{array}{l}\text { Female } \\ \text { (twin) }\end{array} & \begin{array}{l}\text { Art club* } \\ \text { Brownies }\end{array} & \text { Flute lesson* } \\ 44 & \text { Male } & \text { Football } & \begin{array}{l}\text { Scouts } \\ \text { Multi-skill } \\ \text { club* }\end{array} \\ 59 & \text { Female } & & \text { Karate }\end{array}$

lesson

Swimming Junior club

lesson

Football*

Dodgeball*

Guides

Football*
Street dance

Triathlon club

Horse riding

Swimming

Football

lesson

Tennis

n.b. An asterisk (*) indicates that the activity was school-based. 
TABLE 7 Organised sporting activities participated in by the children according to provider status

\begin{tabular}{|c|c|c|c|}
\hline & $\begin{array}{l}\text { School } \\
\text { provider }\end{array}$ & $\begin{array}{l}\text { Non-school } \\
\text { provider }\end{array}$ & $\begin{array}{l}\text { Both school } \\
\text { and non-school } \\
\text { provider }\end{array}$ \\
\hline $\begin{array}{l}\text { Under-class } \\
\text { (6 activities) }\end{array}$ & $\begin{array}{l}\text { Street dance } \\
\text { Tag Rugby }\end{array}$ & $\begin{array}{l}\text { Swimming } \\
\text { Basketball } \\
\text { Dance }\end{array}$ & Football \\
\hline $\begin{array}{l}\text { Lower-middle- } \\
\text { class (8) }\end{array}$ & $\begin{array}{l}\text { Running club } \\
\text { Dodgeball } \\
\text { Orienteering } \\
\text { Netball }\end{array}$ & $\begin{array}{l}\text { Swimming } \\
\text { Hockey }\end{array}$ & $\begin{array}{l}\text { Football } \\
\text { Dance }\end{array}$ \\
\hline $\begin{array}{l}\text { Mid-middle- } \\
\text { class (26) }\end{array}$ & $\begin{array}{l}\text { Dodgeball } \\
\text { Fencing } \\
\text { Judo } \\
\text { Netball } \\
\text { Orienteering } \\
\text { Running club } \\
\text { Tag Rugby }\end{array}$ & $\begin{array}{l}\text { Athletics } \\
\text { Badminton } \\
\text { Basketball } \\
\text { Cricket } \\
\text { Diving lesson } \\
\text { Gymnastics } \\
\text { Horse riding } \\
\text { Ice skating } \\
\text { Jujitsu } \\
\text { Kayaking } \\
\text { Rugby } \\
\text { Street dance } \\
\text { Swimming } \\
\text { Tennis } \\
\text { Trampolining } \\
\text { Triathlon club }\end{array}$ & $\begin{array}{l}\text { Dance } \\
\text { Football } \\
\text { Hockey }\end{array}$ \\
\hline $\begin{array}{l}\text { Upper-middle- } \\
\text { class (24) }\end{array}$ & $\begin{array}{l}\text { Badminton } \\
\text { Basketball } \\
\text { Cross country } \\
\text { Dodgeball } \\
\text { Fencing } \\
\text { Hockey } \\
\text { Multi-skill } \\
\text { Netball }\end{array}$ & $\begin{array}{l}\text { Cycling club } \\
\text { Dance } \\
\text { Golf lesson } \\
\text { Horse riding } \\
\text { Karate } \\
\text { Mountain } \\
\text { Biking } \\
\text { Rowing } \\
\text { Rugby } \\
\text { Street dance } \\
\text { Tae Kwondo } \\
\text { Tennis } \\
\text { Triathlon } \\
\text { Water skiing }\end{array}$ & $\begin{array}{l}\text { Cricket } \\
\text { Football } \\
\text { Swimming }\end{array}$ \\
\hline
\end{tabular}

